\title{
Low-Carbon Communities between Vision and Implementation The Case of Borg Al Arab
}

\author{
Dr. Riham Nady \\ Lecturer, Department of Architectural Engineering Pharos University in Alexandria, Egypt \\ rihamnady@hotmail.com
}

\begin{abstract}
Several cities are facing the problem of running-out of fossil fuels and are contributed to an estimated $70 \%$ of the world's energy-related greenhouse gases (GHGs). Consequently, there is a tremendous need for low-carbon communities which will lead to more livable, efficient and ultimately sustainable cities. Furthermore, well-planned and designed communities can effectively provide the basic human needs and reduce reliance on fossil fuels. Some communities have developed strategies to reach net zero-carbon future by reducing demands for energy and supplying the remaining demands with renewable resources.
\end{abstract}

In the meantime, Egyptian cities face the problem of greenhouse gases and the lack of energy and water. Therefore, passive, energy efficient and energy offset design are needed. This can be achieved through sustainable transportation systems and the shift to efficient management of water and waste.

The paper discusses the problem of climate change and its relation with communities. It investigates examples of communities that have focused on reducing their carbon emissions in different parts of the world. Also, it examines some of the most important aspects of design strategies that help to implement low-carbon communities and how could they be achieved in the Egyptian context (Borg Al Arab-Alexandria).

The aim of the paper is to highlight certain cities that demonstrate a deeper understanding of what a lowcarbon community is and how to achieve it through reducing energy demand and providing the best options for passive design and renewable energy supply in the Egyptian communities to become selfcontained in terms of energy.
Keywords - energy-efficient; grenhouse gases; lowcarbon communties; renwable energy sustaianbilty

\section{INTRODUCTION}

The tremendous increase in energy use in Egypt has caused many environmental problems and lack of resources. These problems can be solved through planning low-carbon communities in the urban extensions of cities. Presented here is a methodology for generating appropriate energy design guidelines for these new communities through analyzing different examples that have adopted these strategies in their urban planning to achieve low-carbon goals. The study starts by discussing the problem of climate change in cities and the need for low-carbon communities. Also, it presents the history and evolution of low-carbon communities and their different concepts. Then, the study tackles different low-carbon urban strategies through passive, energy efficient and offset design. A future model for Borg Al Arab (Alexandria) is proposed through the main guidelines for planning of low-carbon communities. Finally, the paper ends up with a SWOT analysis for the design of low-carbon communities to compare points of strengths and weaknesses of low-carbon concept. The paper proposes different low-carbon strategies and aspects to be applied in the Egyptian context and across the developing world.

\section{CITIES AND CLIMATE CHANGE}

Cities and climate change have a dual relationship. Cities, as major emitters of greenhouse gases, contribute to climate change. The changing climate would cause severe impacts on cities, as they have the increasing majority of the population and productive assets. Nevertheless, globally, city planners are now increasingly paying attention to climate change for three key reasons. First, the 
participation of cities is vital in achieving national environment and development goals. Second, since cities hold most of the financial, institutional and intellectual capitals, their attractive participation is essential in formulating and implementing national climate change mitigation and adaptation policies. Finally, cities are sizable co-benefits of climate change, such as improvements in air quality, traffic congestion and reduction of heat island effects, which would accrue by aligning climate change and development policies [1].

Thus, the activities of urban settlements are key contributors to climate change factors. Climate change is characterized by the irreversible build-up of greenhouse gases (GHGs) and global warming at a potentially huge cost to the economy and the society worldwide. Much of the greenhouse gases in the atmosphere are driven by human activity which is already affecting the global climate. Emissions of carbon dioxide (the principle greenhouse gas) have risen more than ten-fold since the start of the industrial revolution. Also, the atmospheric concentrations of carbon dioxide have risen more than $30 \%$ and are projected to reach twice the preindustrial level by the middle of this century [2].

World GHG emissions have roughly doubled since the 1970s and on current policies could rise by over $70 \%$ during 2008-2050. Historically, energy-related GHG emissions were predominantly from richer developed countries. However, today two-thirds of the flow of new emissions into the atmosphere is accounted for the developing countries [3].

At present, growth rates of developing countries' emissions are expected to surpass those of developed countries within a matter of decades due to the rise of populations, low income levels and the extreme of energy use. In the meantime, it is estimated that the costs of inaction on climate change will be large particularly in many developing countries such as the rise of sea levels, the intense of heat waves and the decline of agricultural yields in rural areas. Even more, each degree in global warming increases irreversible damage worldwide [2].

To address the threat of climate change, GHG emissions are to be solved, stopped and reversed. Meeting the challenge will require dramatic advances in technologies and a shift in how the world economy generates and uses energy [4].
Thus, all instruments are being mobilized to reduce net emissions to zero and to adopt the existing emissions according to a climate change policy. It is required to change the way in which the buildings are spatially configured and served and the way in which communities are planned to reach low-carbon communities that would contribute to climate change protection.

\section{THE EVOLUTION OF LOW-CARBON COMMUNITIES}

The planning and design of traditional settlements saves much energy through the pattern and structure of buildings which aimed to minimize the use of energy consumed in travelling between essential activities and also in the operation of buildings. It also assumes high degrees of self-sufficiency at levels of settlement structure. There are common structural and physical features in the layout in most of the desert cities. The complicated and interrelated factors that have shaped historic architecture and urban form in desert regions are mostly affected by climatic characteristics.

The urban form of traditional Arab cities is highly centralized or inward looking "Figs.1 and 2". Certainly, the orientation and relation to the environment have been of high importance in the planning of city. The particular climatic problems caused the people of the hot arid zone to find solutions to their settlements' architecture. The high radiation and temperature in the summer, diurnal variations of temperature, seasonal variations from dry hot summer to cold dry winter, low humidity, limited water supplies and the dusty winds are the most important factors in forming the urban structure of such settlements [5].

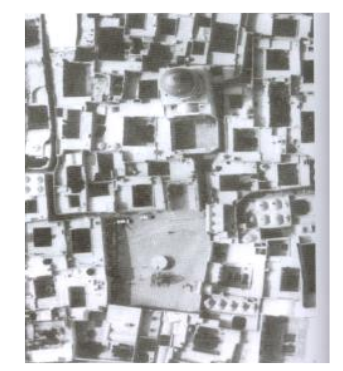

Fig .1. The concentrated urban form of old cities 


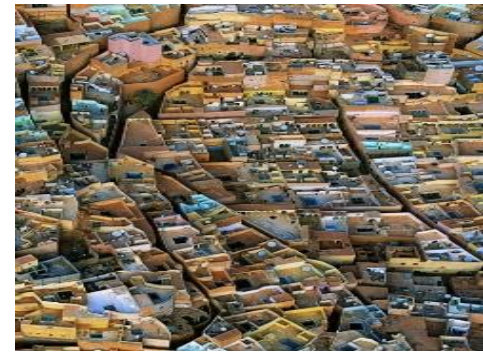

Fig .2. Compact buildings in Old Algeria

The arrangement of buildings appears to be compact in layout. This is ecologically held up as a model for city planning to minimize the heat flow into the buildings, thus applying human comfort. It is also characterized by uniformity in urbanization. These settlements promote walking and cycling as the main modes of movement. The main objective of a traditional city planning is to establish the optimum orientation of buildings with regard to the sun and the prevailing winds.

The layout of almost all traditional cities in hot arid regions is characterized by some features such as narrow widening streets, large open courtyards and internal gardens. This design reduces the cooling load transmitted through the building shell and makes natural ventilation more desirable and effective. Based on these examples, Hassan Fathy introduced the traditional planning of cities "Fig.3". He employed narrow streets and introverted houses with inner courtyards in his design of the village of New Bariz [6].

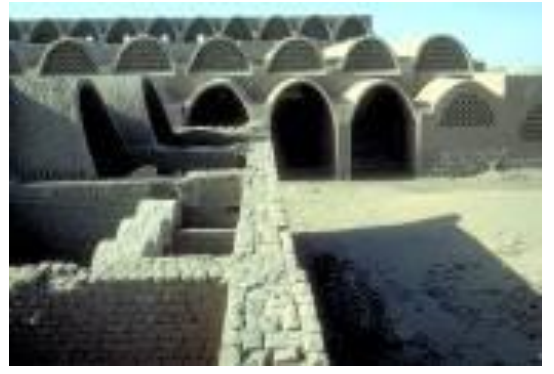

Fig. 3. New Bariz village by Hassan Fathy

\section{CONCEPT OF LOW-CARBON COMMUNITIES}

Low-carbon communities are more realistic and could address the emergence of urban scale that would generate renewable energy systems. A low-carbon community is "one that has greatly reduced energy needs through efficiency gains such that the balance of energy for vehicles, thermal and electrical energy within the community is met by renewable energy" [7]. This means that, it minimizes the energy demand within the boundaries through promoting energy efficiency and balancing the energy consumption and the facilitation of renewable energy.

The energy performance of a low-carbon community or a net-zero community can be accounted for in several ways. The definitions listed below are based on those by Torcellini (2006):

\section{A. Net-Zero Site Energy}

A net zero site energy produces at least as much renewable energy as it uses over the course of a year when accounted for at the site. The net zero site energy concept measures the building's site, ignoring whether the utility source is coal or wind.

\section{B. Net-Zero Source Energy}

A net source zero energy building (ZEB) produces at least as much renewable energy as it uses over the course of a year when accounted for at the source. Source energy refers to the primary energy used to generate and deliver the energy to the site.

\section{Net-Zero Energy Costs}

In a cost ZEB, the amount of money the utility pays the building owners and the community (for renewable energy generated on all residential and community buildings and infrastructure) for the energy the building exports to the grid is at least equal to the amount the owner pays the utility for the energy services and energy used over the year. If transportation is included, the cost of the fossil-based fuels is offset by fuel generated from renewable resources.

\section{Net-Zero Energy Emissions}

A net-zero emissions community produces and uses at least as much emissions-free renewable energy as it uses from emissions-producing energy sources annually.

A community may be designed to achieve one or more of the above definitions but may not achieve it in actual operations every year. If the community produces at least $75 \%$ of its required energy through the use of on-site renewable energy, it is considered a near-zero or low-carbon community [7]. 


\section{LOW-CARBON COMMUNITIES DESIGN STRATEGIES}

Low-energy design has probably the greatest direct impact on the nature of cities and communities' life. However, urban design and fundamental principles of how to shape the communities have so far barely featured in the greenhouse debate. The movement towards low-energy design in urban planning may result from the influence of a variety of interconnected factors including the design and technological advancements, ethical considerations, economic costs and opportunities, risk management and marketability. The challenge is to design a community where people live, while also have the flexibility to evolve and work well environmentally, socially and economically, both now and for the future [8].

It is necessary for architects and design professionals to understand low-energy drivers and to consider them at the beginning of the design stages and to continue throughout the construction phase (Table 1). This section provides an overview of low-carbon deign strategies and guidelines which discuss various aspects and scales of interventions for energy efficient urban planning structured according to the following categories:

Table 1. Low-carbon communities' design strategies

\begin{tabular}{|l|l|l|}
\hline $\begin{array}{l}\text { Design at Building } \\
\text { Level }\end{array}$ & \multicolumn{2}{|l|}{ Design at Urban Level } \\
\hline Passive Design & $\begin{array}{l}\text { Energy Efficient } \\
\text { Design }\end{array}$ & $\begin{array}{l}\text { Offset } \\
\text { Design }\end{array}$ \\
\hline - Building massing & $\begin{array}{l}\text { - Green and } \\
\text { pedestrian spaces }\end{array}$ & - Energy \\
Management \\
- Building type & - Mobility and & technologies \\
- Architural elements & Accessability & - Water \\
- Sustaianble building & (sustainable & management \\
materials & transport) & - Waste \\
& Sustainable food & management \\
\hline
\end{tabular}

\section{A. Passive Design}

\section{- Building massing}

The configuration of building mass is related to specific climate type and the influence indoor and outdoor comfort. Certain building typologies increase shading and ventilation, which can reduce the cooling load. The recommended elements of the urban form in hot-dry climates are low-rise, high-density and narrow streets to achieve optimal energy efficiency where buildings can provide shade on each other, and thus lower cooling loads. The shading of streets is maximized, to create a more comfortable microclimate for pedestrians. [9].

This climate-sensitive urban form is seen in Hashtgerd New Town (Iran) which is based on passive design "Fig.4". It bears considerable mitigation and adaptation potentials by reducing energy consumption especially for cooling and heating without losing thermal comfort. The 35 hectares area exploits this potential by referring to the traditional Iranian city whose characteristics are translated into a dense and compact urban form with a clear hierarchy of public, semi-private and private spaces and access systems in a low-rise-high density design. The proposed twenty-nine compact neighborhood clusters are organized in four rows, stretching from north to south and are located on the ridges of the hills on the site allowing the main and hot winds from west and northwest to channel through the site "Fig. 4 and 5". Every cluster (approximately $15 \times 30 \mathrm{~m}$ ) and four building groups are arranged around it.

The clusters are accessible by foot and bike via a narrow $6 \mathrm{~m}$ wide path in the north-south direction. All clusters are connected through these paths which allow for a compact urban fabric and a reduction for traffic areas. The organization of each housing group supports the compact form since it is considered as a major need for achieving this low-carbon city. This compactness contributes to the reduction of direct solar radiation and thermal loss. The orientation of buildings in Hashtgerd is another major aspect for energy efficiency. The predominant north-south orientation of the buildings reduces the cooling demand by up to $23 \%$ and the heating demand by up to $16 \%$. Also, the low skyline follows the topography of the site allows for free movement of air above the city [10].

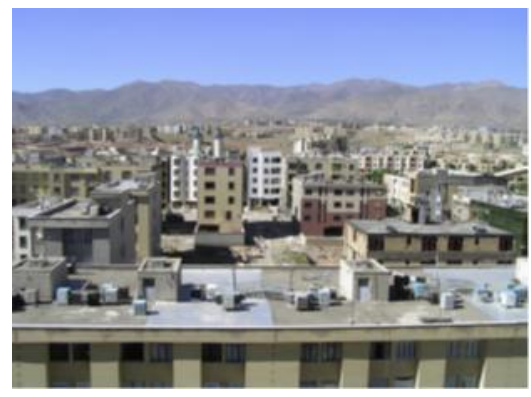

Fig .4. Hashtgerd New Town (Iran) 


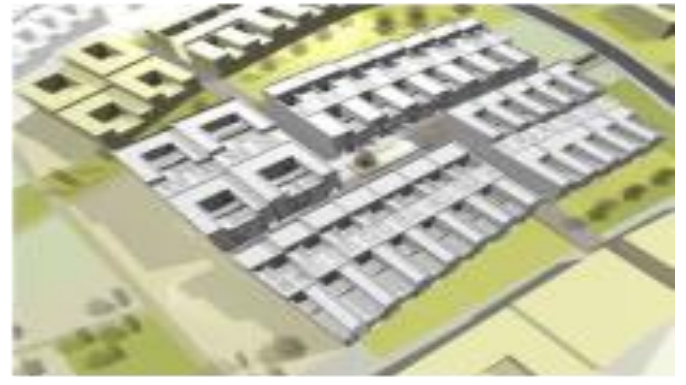

Fig .5. The dense and compact urban form of the $35 \mathrm{ha}$ area

\section{- Building type}

Building typology, form and design can cater to various aspects of passive cooling for a comfortable indoor climate and reduce the cooling loads of buildings. Passive design strategies (for sun and wind), guide urban fabric development for low-carbon communities at the building level and improve the micro-climate through reduced solar gain. On one hand, the architectural concept is addressed through optimal use or protection from the solar radiation, for both building and outdoor space. Building envelopes should be oriented along the east-west axis. The south facing facades are designed to have small openings and horizontal shading. On the other hand, buildings are oriented in such a way that the prevailing winds can be used for most optimal natural ventilation [9].

\section{- Building architectural elements}

Building envelope designs are created through the optimization of window-wall ratios, allowing sufficient daylight, while minimizing the openings that provide heat gain. Window shading concepts are used in order to match the climatic conditions, maximize natural light and ventilation. Green roofs are to be promoted, as they improve the shading and thermal capacity of the building envelope and reduce the solar heat gain [9].

\section{- Sustainable building materials}

The design process offers greater opportunities for reducing environmental impacts through material selection. One of the primary concerns in selecting building materials is to avoid negative impacts on health and provide safety and comfort for building users. Also, identification of materials and products that contribute to energy efficiency is one of the primary selection criteria [11]. Natural building materials such as stone, brick and wood require minimal processing and energy inputs. They are characterized by their durability, adaptability and low construction impact. Also, the use of local and regional materials enables energy savings in transport and compatibility with local building traditions which support the local economy [12].

\section{B. Energy Efficient Design:}

Energy efficient urban design may require the use of new designs and technologies.

\section{- Green and pedestrian spaces}

Communities are principally made up of buildings and infrastructure. However, they contain a significant proportion of open spaces. On one hand, green open spaces such as parks, protected green spaces, gardens, street trees and landscaping provide a high quality of life and a number of vital ecosystem services, acting as "green lungs" which absorb and filter air pollution. They also provide a habitat for wildlife and offer recreational benefits for the community residents [13].

Also, to support the short distances and mix of uses, pedestrian networks need comfortable micro-climatic conditions in order to access services and amenities easily without depending on private automobiles. A comfortable outdoor pedestrian space is created through the use of porous, light colored-materials for outdoor public spaces and surfaces. It leads to the reduction of urban heat island effect and thereby lowering the outdoor ambient temperature and the reduction of cooling loads of adjacent buildings. Native vegetation uses less water and provides dust protection which enhances natural ventilation for public outdoors and buildings and reduces the reflective humidity supporting a more comfortable outdoor space [9].

This strategy is applied in Xeritown (Dubai-U.A.E.), where there is a boulevard which ties together the urban public elements of cafes, restaurants, lobbies and retail shops. They are all shaded by deep arcades on one side of the promenade and landscape on the other. The most public part of the development is framed by the urban sun shading (an ornamental roof structure composed of photovoltaic panels providing low-voltage direct current electricity) which turns the promenade into a place for strolling, sitting and 
watching or waiting for the bus "Figs.6 and 7". The landscape can be explored by walking or via jogging or cycling track which runs through it. Xeritown thus, encourages a public life outdoors at least in winter months [14].

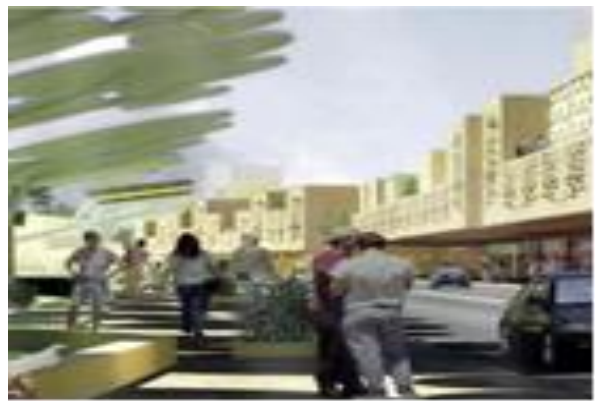

Fig .6. Sun shading with photovoltaic panels in the streets of Xeritown

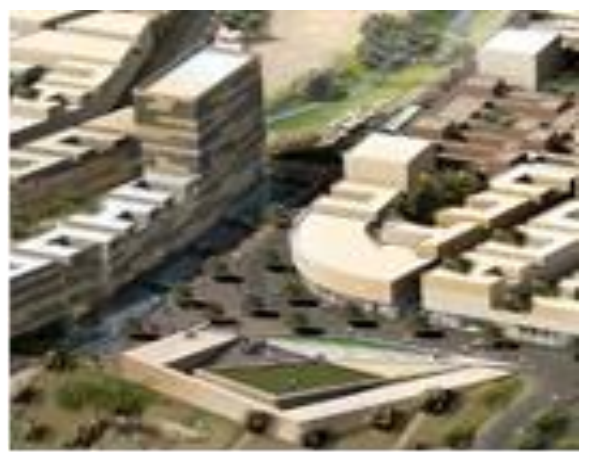

Fig .7. Public outdoor spaces in Xeritown

- Mobility and accessibility (sustainable transport)

Current transport patterns are based primarily on motorized vehicles which generate many social and environmental problems and economic costs. They represent a significant source of greenhouse gas emissions and can affect the community and urban planning in a direct way. These unsustainable patterns of transport are expected to worsen under the conditions of rapid trend of motorization [15]. The approach of low-carbon transportation reduces greenhouse gas emissions and can be maintained through the high shares of low-carbon modes of transport and at the same time shifting to environmentally-friendly technologies and enabling a less car dependent mobility [16].

In order to ensure efficient ways of transporting people and goods, new communities need to be planned including easy access to various types of mobility such as bicycles, bus (light rail), shared taxi or car pooling within short distances. Within the community site itself, cycling can be encouraged by providing accessible, secure and covered bicycle storage [8].

Also, low-carbon communities need to be designed to use sustainable transport by offering walkable transit oriented options, often supplemented by vehicles powered by renewable energy "Fig. 8 and 9". Communities with sustainable transport systems are able to reduce their ecological footprints from their reduced use of fossil fuels as well as their reduced dependence upon car-based infrastructure [17].

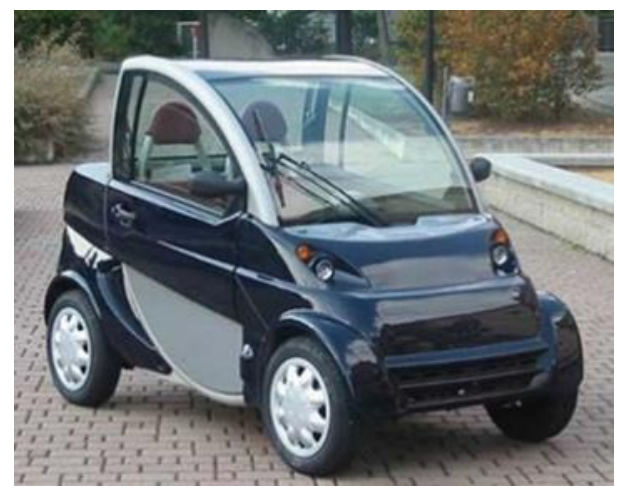

Fig .8. Electric powered vehicle

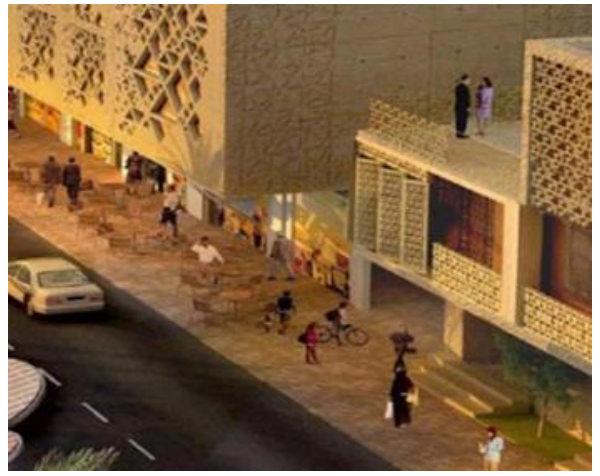

Fig .9. The vehicular streets in Xeritown are limited to two lanes

This strategy is achieved in Xeritown (Dubai, U.A.E.) where it is considered mainly as a pedestrian neighborhood.

The design of Xeritown reduces pollution, encourages pedestrian movements and represents a compromise solution with vehicular streets limited to two lanes. Consequently, this arrangement discourages driving, encourages public transportation and reduces private vehicular transportation to a minimum. The city's extensive shaded and well-ventilated pedestrian and cycling networks, together with the proposed public 
transport network, all work together to reduce the carbon emissions emitted by the city's transportation systems.

\section{- Sustainable local food}

Food has significant impacts on the green credentials, especially if one takes into account the energy use generated by transporting food from remote locations to urban places. Reducing the environmental problems associated with food consumption involves changing the current food culture. Locally produced food reduce carbon dioxide emissions from present approximately one-tenth of the energy consumption of conventional housing. Energy systems include heat pumps, a heat recovery system, solar hot water collectors and photovoltaics. Each house has its own photovoltaic system to generate electricity "Figs. 10 and 11". Based on the size and needs of the housing unit, the photovoltiac systems have outputs that vary from 3.0 to $12.0 \mathrm{KW}$ [19].

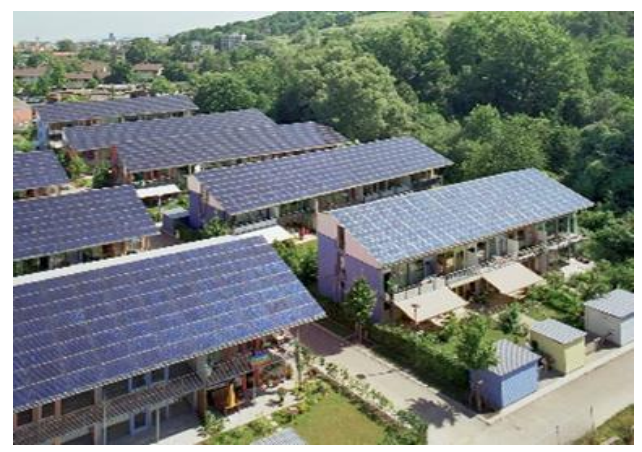

Fig .10. Solarsiedlung am Schlierberg complex (Germany)

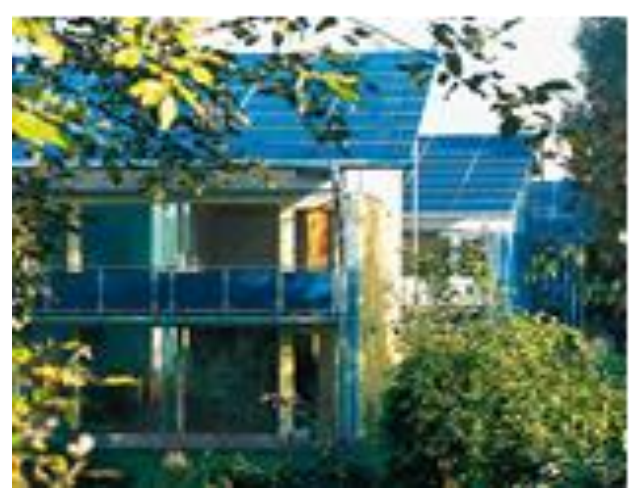

Fig .11. Each house has its own photovoltaic system to generate electricity

\section{- Water management}

In many areas of the world, especially in hot arid urban regions, demand for water exceeds supply and is seriously straining available water resources.
Excessive water usage can degrade local water resources, threatening the availability of water for local future needs [11].

Water management is considered as one of the main elements to achieve low-carbon communities. This can be achieved through a number of conservation measures which can be used in communities. Also, water reduction measures can conserve and protect local water resources upon which the local community depend. In the meantime, preserving the quality of local water resources can eliminate the need for costly drinking water treatment processes. Reduction of water use requires the implementation of strategies at both the building and site scale. The consumption of primary water can be reduced to less than half the current use through applying water efficiency strategies such as low-flush fixtures, automatic controls and water-saving devices for kitchens and bathrooms, as they reduce the flow of water by $50 \%$ without affecting the comfort level of the user.

Also, it is important to use the roofs of buildings to collect rainwater instead of allowing all water landing on the building's roof to run into stormwater drains. Water is captured, stored and prepared for future uses. Designing the roofs and angling them properly can result in a maximum intake of rainwater [12]. Furthermore, water reuse and recycling technologies can be economical and efficient to reduce a building's overall water consumption by directing appropriate wastewater to other uses such as irrigation [18].

This wastewater concept is introduced in Hammarby Sojostad (Stockholm) which initiated the first step to water supply in a sustainable approach. The reduction of water is achieved by installing low-flush toilets and fixtures in all housing units. Hammarby Sojostad's wastewater (sewage) is treated at Stockholm's Henriksdal's plant. A new experimental treatment plant is testing innovative alternative system for stormwater that it would be treated as a landscape feature. Stormwater from buildings and courtyards is detained in a stormwater bio-swale canal and in paved gutters before being released into Lake Hammarby. The goal for street-water runoff is that it would be collected on-site in setting tanks and filtered. In this way, all rainwater and snowmelt from streets is drained into holding basins and then into settling tanks [20] "Figs.12". 


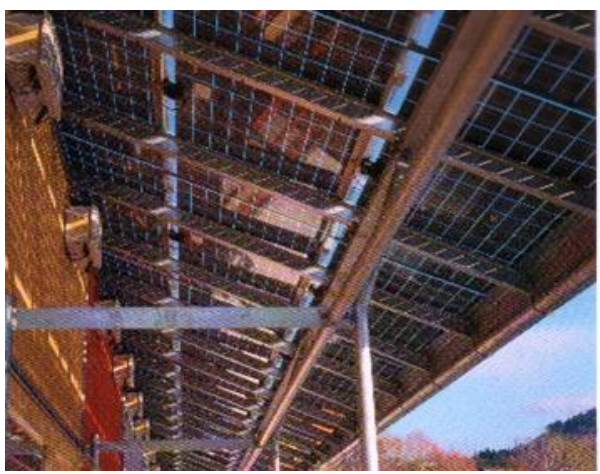

Fig .12. Storm water retention in Hammarby Sojostad (Stockholm)

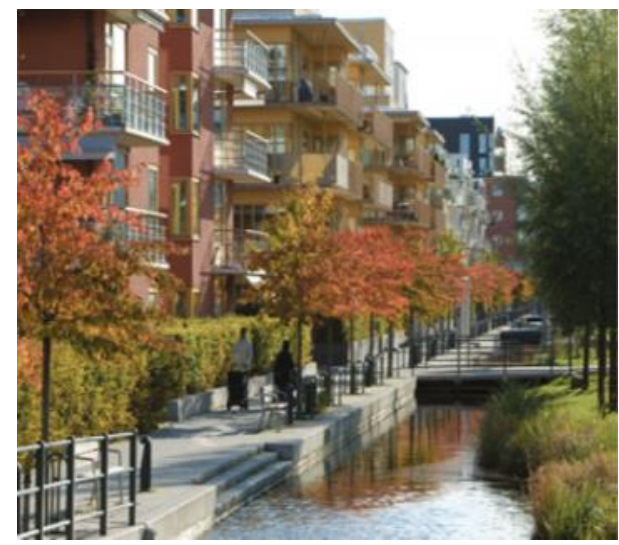

Fig .13. Detail of the south-facing photovoltaic array

\section{- Waste management}

Buildings produce large quantities of waste (solid and liquid). In many cases, this waste is collected in badly designed damps, discarded directly in rivers or simply damped in areas out of site [10]. However, low-carbon communities have demonstrated considerable resilience in finding green solutions that reduce the overall waste, increase recycling and finding new forms of environmentally friendly treatment of unavoidable waste [13].

Waste management begins by reviewing the types and quantities of waste produced and the current disposal methods and costs [21]. Waste reduction means minimizing the quantity of waste that is going to disposal. Also, reuse and recycling are necessary to prerequisite the provision of easily accessible and well served areas for separate collection of glass, paper, plastics and metal with local recycling possibilities [12].

Also, composting solid waste technology generates a small amount of energy from a given quantity of waste and it requires a large amount of waste to become viable. Advanced thermal treatments turn waste into energy rich fuels through heating the waste under controlled conditions. Such approaches to generate energy from waste require new technologies and management systems that integrate public health and environmental engineering with ecological planning [21].

In Hammarby Sojostad (Stockholm), waste is recycled into natural gas which is used as an energy source for the neighborhood. Heat produced through the purification process is recycled for use at a district heating unit. Also, Hammarby Sojostad has its own pilot sewage treatment center where nutrients are recycled from sewage for use on agricultural land. Any combustible waste produced is recycled into heat energy for use in the apartments. Each apartment block has recycling facilities and biodegradable waste is composted nearby.

Eliminating the concept of waste is the most comprehensive approach to waste removal, however, reducing the initial flow of waste is an important step. Hammarby Sojostad sets the goal of reducing solid wastes by $15 \%$ and, further, has taken the most the remaining flows [20].

\section{LOW-CARBON COMMUNITIES IN EGYPT (A FUTURE MODEL IN BORG AL ARAB ALEXANDRIA)}

The governorate of Alexandria consists of three individual cities which are Alexandria, Borg Al Arab city center and New Borg Al Arab. Borg Al Arab is located about $45 \mathrm{~km}$ south-west Alexandria city center and seven kilometers from the Mediterranean coast. North of Borg Al Arab city is King Mariout and Mariout Lake. It is surrounded on all sides by a green belt with a surface area of 18,000 feddans. The city has an airport that serves nearly 250,000 passengers every year and also has the biggest stadium in Egypt. Borg Al Arab is seen as the natural extension for Alexandria city yet suffers a continuous environmental abuse from man-made viloations. It has been subjected to unplanned urbanization as well as discharge of heavy industrial pollutants. Thus, the city of Borg Al Arab faces several problems which can be summarized as follows:

- Urban structure:

Deteriorated conditions of services and the inability and imbalanced urban growth (industry vs. housing). 
- Residential housing:

Low settlement rate due to the lack of housing for factory workers and hierarchy of centers.

- Industrial factories:

They are causing air and noise pollution due to heavy traffic of transporting factory material at the entrance of the city and industrial zones.

- Transportation:

Lack of public transport and mass transit modes that connect Borg Al Arab with Alexandria city center.

- Traffic:

High traffic volume at northen and southern city centers.

- Utilities and infrastructure:

High voltage power lines inside the city and low water pressure in some districts.

- Environment:

Common drainage network is used for both industrial and domestic wastewater, lack of industrial solid waste collection and disposal systems, lack of building and agricultural solid waste collection systems.

- The governance system:

There is no single authority managing the city and the residents of the area do not participate in the decision of uses in the area [22].

\section{GUIDELINE FOR TRANSFORMING BORGAL ARAB TO A LOW-CARBON CMMUNITIY}

The development plan for Borg El Arab aims at optimizing the utilization of natural resources without causing any ecological disequilibrium in this vital and important zone of the city of Alexandria. Also, it aims to improve and transform the current city and change it to a low-carbon community. This will ensure equal opportunities for generations to come. Within the next ten years, Borg Al Arab would be an investment magnet, a job creator, a visitors' attraction spot within the city of Alexandria. The broad aim is to create a socio-economic, environmental, urban and infrastructure foundation that would initiate a successful low-carbon development.

Borg Al Arab is found to have great potentials to be transformed to a low-carbon community and thus helps in the reduction of carbon emissions and the negative effects in the area. After analyzing the previous examples of zero-energy communities and explaining their strategies and guidelines that can be applied to reach a low-carbon community, it is found that Borg Al Arab should undergo some changes in order to be transformed.

The proposed transformation guidelines are divided into immediate, medium and long-term action plans. The sustainable, low-carbon vision of Borg El Arab can be displayed in a set of objectives as follows:

\section{A. Passive Design:}

- Building massing

The most cost-effective step towards a reduction in a building's energy consumption is the form of buildings. Thus, it is proposed to create low-rise, high-density buildings with a proper network of narrow streets in between to achieve optimal energy efficiency and solve the problem of urban structure.

\section{- Building types, features and materials}

It is important that buildings should be oriented northsouth to get the optimal benefit from the prevailing winds and achieve natural ventilation. Buildings should be constructed from local building materials found in the surrounding context. These materials should be of a high quality, durable and flexible. This will lead to find a solution for the residential housing problem [22].

\section{B. Energy-Efficient Design:}

\section{- Green and pedestrian spaces}

It is important to enhance the area of Borg Al Arab with attractive uses, high quality public spaces. Parks and open spaces are necessary to a vital urban extension like Borg Al Arab. Moreover, it is proposed to extend high quality public facilities by linked green areas which provide a central focus for Borg Al Arab. 
- Mobility and accessibility (sustainable transport)

It is encouraged to use clean and economic forms of transportation such as bicycles and public transit, ......etc. The city should be easily accessed due to its regional location which enhances its competiveness and makes it easy to access Borg Al Arab via the airport and the Alexandria marine port. Also, the area is connected to the international and coastal roads. It is recommended to enhance the existing network of transport by increasing the capacity and quality and redistribute the nodes geographically in the area as well as developing new connections to Borg Al Arab.

\section{- Sustainable local food}

It is proposed to implement and create vast areas suitable for agriculture to be able to grow local food which provides the residents with healthy and fresh resources. Also, it will help to reduce carbon dioxide emissions from transport and it will help strengthen the local agriculture economy. Also, it is proposed to create small gardens or exploit roof tops for growing food.

\section{Energy Offset Design:}

\section{- Energy Management technologies}

It is proposed to use renewable energy solutions through future plans for establishing solar-operated electric plants to generate the electricity needed in the area. This can be achieved through creating a field of photovoltaic cells (PVs) which can be placed in a land near Borg Al Arab. Also, it is proposed to create large wind turbine farms to supply the area with the energy needed. In this way, the problem of energy will be solved substantially.

\section{- Water management:}

People should learn how to use water and this might need to increase the awareness for water preservation. It is proposed to reduce the environmental degradation of water, increase the capacity and quality of existing sewerage and water systems and enhance wastewater treatment. Also, it is proposed to serve all residential areas with potable water and to incorporate smart water appliances in the buildings. Furthermore, it is encouraged to use treated recycled water in irrigation and other non-potable services.
- Waste management:

There is a real need for industrial and agriculture solid-waste collection and creating disposal systems. It is proposed to sort and separate wastes at source into four individual basins, each one is used for a specific material, for example, one basin for plastics, metal, glass and paper. Trained workers should collect the wastes and recycle them to be used again in the area.

Thus, Alexandria's environmental and comprehensive development strategy plan aims at solving the problems found in Borg Al Arab and at improving the quality of life and citizens' comfort. Also, it puts into act projects that would ensure the city's sustainable development based on low-carbon design tools .

\section{LOW-CARBON COMMUNTIES BWTWEEN VISION AND IMPLEMENTATION}

In order to keep the communities alert to staying green and sustainable and achieving the low-carbon applications in Borg Al Arab, it is important to learn how to be sustainable and have the knowledge needed for that to maintain the qualities given by that way of life. In the meantime, it is important to make SWOT analysis (Table 2) for the points of strengths, opportunities, points of weakness and threats for the design and planning of low-carbon communities to know if it can be implemented and achieved or not.

Table 1. SWOT analysis for low carbon communities

\begin{tabular}{|c|c|c|c|}
\hline \multirow{10}{*}{ 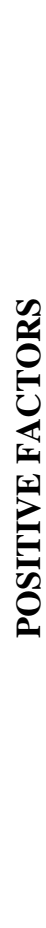 } & Strengths & Weaknesses & \multirow{10}{*}{ 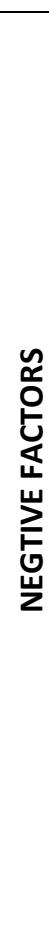 } \\
\hline & $\begin{array}{l}\text { 1. Reducing carbon } \\
\text { footprint and minimizing } \\
\text { emissions of greenhouses } \\
\text { gases (GHGs) }\end{array}$ & $\begin{array}{l}\text { 1. Requiring certain } \\
\text { restrictions and } \\
\text { qualifications }\end{array}$ & \\
\hline & $\begin{array}{l}\text { 2. Minimizing energy } \\
\text { consumption }\end{array}$ & $\begin{array}{l}\text { 2. High costs of } \\
\text { technologies }\end{array}$ & \\
\hline & $\begin{array}{l}\text { 3. Energy conservation } \\
\text { strategies }\end{array}$ & $\begin{array}{l}\text { 3. Difficulty in changing } \\
\text { people's } \\
\text { behavior }\end{array}$ & \\
\hline & $\begin{array}{l}\text { 4. The use of energy- } \\
\text { efficient technologies }\end{array}$ & 4. Require large site areas & \\
\hline & $\begin{array}{l}\text { 5. Making people aware of } \\
\text { the carbon impact }\end{array}$ & $\begin{array}{l}5 . \quad \text { Difficulty } \\
\text { governmental } \\
\text { regulations }\end{array}$ & \\
\hline & Opportunities & Threats & \\
\hline & $\begin{array}{l}\text { 1. Self-sustaining in terms } \\
\text { of } \\
\text { energy needs }\end{array}$ & $\begin{array}{l}\text { 1. Funding low-carbon } \\
\text { designs require massive } \\
\text { amounts of energy, water } \\
\text { and land. }\end{array}$ & \\
\hline & $\begin{array}{l}\text { 2. Encouraging passive, } \\
\text { energy efficient and offset } \\
\text { design and planning } \\
\text { strategies }\end{array}$ & $\begin{array}{l}\text { 2. Funding low-carbon } \\
\text { projects comes from } \\
\text { unsustainable means }\end{array}$ & \\
\hline & 3. Economic advantages & & \\
\hline
\end{tabular}




\section{CONCLUSION}

The paper shed light on an important community in the city of Alexandria (Borg Al Arab) which is rich because of its location and potentials. A land use strategic vision has been proposed providing a way forward to a sustainable low-carbon community which achieves low-energy goals preserving the natural, socio-cultural and economical dimensions of sustainability.

This system of criteria and indicators for a low-carbon community is meant to function as an aspiration for decision-makers, organizations, planners and interested citizens. It has to be underlined that a part of the process towards low-carbon developments and the use of criteria and strategies are crucial because it is all about quality of life and concrete impact and lasting solutions. Low-carbon urban strategies serve as guidance for all actions, small and big, individual and collective. Therefore, it is necessary to define strategies and guidelines for each community development "Fig.13".

\section{GENERAL FINDINGS AND OUTCOMES}

Leading a community towards low carbon strategies is ambitious and necessary. Fortunately, many cities have begun this innovative kind of future-oriented process. Based on the experience of low-carbon developments in many Arab and European countries, it is of the utmost importance to improve, innovate and modernize policy and management activities towards low-carbon design. Therefore, in case of Egypt (Borg El Arab-Alexandria), it is important to achieve this type of communities to reduce energy demands and provide the best options for passive design, energyefficient and offset deign through the use of renewable energy supply to be self-contained in terms of energy and decrease the effect of climate change and global warming. The achievement of a low-carbon community in Borg Al Arab will be able to substantially improve energy efficiency, conserve non-renewable energy, with various economic advantages. Also, the first and crucial step towards low-carbon is to promote passive design techniques as much as possible, not only for community scale, but also for building scale.

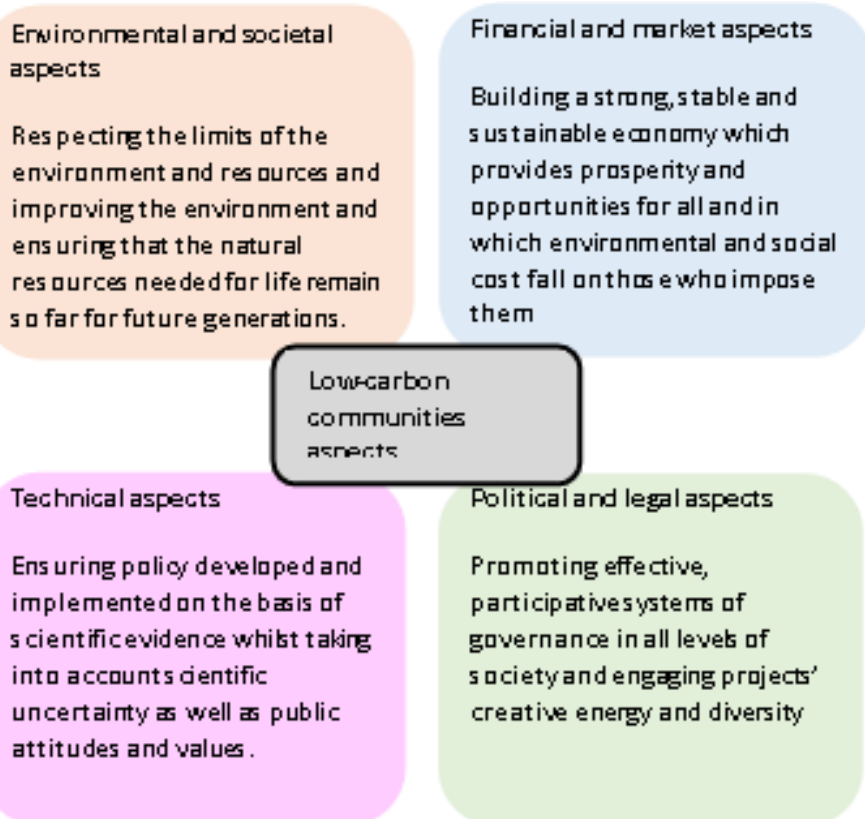

Fig. 14: Aspects of low-carbon communities

\section{RECOMMENDATIONS}

Based on the conclusions discussed before, the following recommendations are madeble:

- Low-carbon communities should be new and distinct from the rest of the cities in order to be a magnet for residents to live and work in it through applying sustainable low-energy urban strategies in the planning process of these communities.

- Support life-styles that move towards low-carbon and zero-carbon energy strategies.

- Increase public's environmental awareness for future challenges to face the environmental issues in Egypt and understand the concept of lowcarbon communities in order to promote the development of zero-carbon developments.

- Public participation through encouraging people to participate in building communities with the new techniques to understand the requirements of buildings and sites.

- Government should lead in reducing carbon emissions through new ideas and project developments.

- The current situation in Borg Al Arab should be identified with its major challenges on the local 
level, and tools should be utilized like SWOTanalysis and sustainability reporting in order to put hand on the real problems and find solutions to it.

- It is important to eliminate the economic problems of the area of Borg Al Arab through dealing with this kind of communities as an important and significant pole in the country by searching the properties of the city which distinguish it from other cities in the same region.

- It is important to address the social problems of Borg Al Arab so as social levels may begin to move to these new communities and create a kind of balanced life which is not limited on the poor and unskilled labor.

\section{REFERENCES}

[1] S. Dhar, M. Pathak, and P.R.Shukla, "Promoting Low Transport in India. Low Carbon City: A guidebook for City Planners and Practitioners", UNEP Centre of Energy, Denmark, August 2013.

[2] W.Chandler, R. Schaeffer, and Z. Dadi, "Climate Change Mitigation in Developing Countries", Prepared for the Pew Center on Global climate Change, October 2002.

[3] Organization for Economic Co-operation and Development (OECD), "Climate Change Mitigation: What do we do?", Australia, 2008.

[4] United Nations Human Settlements Programme, "Planning Sustainable Cities: Global Report on Human Settlements", London, Earthscan Publishing, 2009.

[5] M. Arezou, "The desert city as an ancient living example of ecocity.Case study: Yazd", Published in Ecocity World Summit 2008. 7th International Ecocity Conference. 22-23 April 2008, San Francisco, United States, 2008.

[6] J.Steel, "An Architecture for People: The Complete works of Hassan Fathy", London, Wintney Library of Design, 1997.

[7] N. Carlisle, O. Geet, and S. Pless, "Definition of a "Net Zero Energy" Community", National Renewable energy Laboratory (NREL), Colorado, November 2009.
[8] M. Xameerah, (June 2008), "Eco-towns: Living in a greener future", Department for Communities and Local Government, http://www.raeng.org.uk/societygov/policy/respons es/pdf/Eco Towns consultation.pdf

[9] Energy Efficiency in the Construction Section in the Mediterranean (MED-ENEC), (October 2013), "Energy Efficiency Urban Planning Guidelines for MENA Region", http://www.google.com.eg/url?sa=

$\mathrm{t} \& \mathrm{rct}=\mathrm{j} \& \mathrm{q}=\&$ esrc $=\mathrm{s} \& \mathrm{frm}=1$ \&source $=$ web $\& \mathrm{~cd}=1 \& \mathrm{v}$ ed=0CCIQFjAA\&url=http\%3A\%2F\%2Fwww.enpii nfo.eu\%2Flibrary\%2Fsites\%2Fdefault\%2Ffiles\%2 Fattachments\%2FEE\%2520Building_MEDENEC _Nov2013.pdf\&ei=h6qUU5raJYTqPJnGgYgl\&usg $=$ AFQjCNHVFJvg4objCgK0QlzAifB4r26qOg\&sig2 $=$ TOsFlh8Y99P_JFeXKeUVw\&bvm=bv.68445247 ,d.ZWU.

[10] S. Seeling, "A master plan for low carbon and resilient housing: The 35ha area in Hashtgerd New Town, Iran", Cities, Volume 28, Issue 16, pp. 545-556, December 2011.

[11] Z. Bromberek, "Ecoresorts: Planning and Design for Tropics", New York, Architectural Press, 2009.

[12] P. Gaffron, G. Huismans and F. Skala, "Ecocity Book I: A better Place to Live", Vienna, Facultas Verlags, 2005.

[13] P. Rode and R. Burdett, "Cities: Investing energy and resource efficiency", In United Nations Environment Programme, Towards a Green Economy: Pathways to Sustainable Development and Poverty Education, United Nations Environment Programme, pp.453-492, 2011.

[14] H. Stiftung, "Urban Futures 2030: Urban Development and Lifestyles of the Future", Publication Series on Ecology, Volume 5, January 2011.

[15] K. Sakamoto, H. Dalkmann and D. Palmer, "A Paradigm Shift towards Sustainable Low- Carbon Transport", Institute for Transportation and Development Policy, New York, August 2010.

[16] P. Sassi, "Strategies for Sustainable Architecture", Oxford, Taylor and Francis Group, 2006. 
[17] Department for Communities and Local Government, "Eco-towns: Living in a greener future", 2008.

[18] A.Kwok and W. Grondzik, "The Green Studio Handbook: Environmental strategies for schematic design", Oxford, Architectural Press, 2007.

[19] M. Guzowski, "Towards Zero-energy Architecture: New Solar Design", London, Laurence king Publisher, 2010.
[20] H. Fraker, "The Hidden Potential of Sustainable Neighborhoods: Lessons from Low-Carbon Communities", Washington, Island Press, 2013.

[21] Z. Grant, (December 2009), "Developing Energy Efficient and Zero Carbon Strategies for EcoTowns: Eco-towns Energy Worksheet", Town and Country Planning Association, London, http;//www.tcpa.org.uk/data/files/etws_energy.pdf 